\title{
The Role of Musical and Cultural Factors in Music Teaching
}

\author{
Ruihua Yu \\ Teachers' College of Xi'an University , 710065
}

\author{
Keywords: Music; Culture; Teaching
}

\begin{abstract}
In China's higher education, music teaching has a special status. In recent years, the music teaching in colleges and universities has been paid much attention by the society, and the existing problems are also exposed in the public field of vision. How to do the work of music education in colleges and universities is a realistic problem to be solved in front of every teaching worker. This article briefly analyzes the role of musical and cultural factors in music teaching. The teaching of music in colleges and universities should not be only the learning of music, but also a kind of cultural perception and learning.

Music teaching in colleges and universities is an important part of cultivating students' comprehensive quality. It is an important way to export professional music talents. After the development of these years, the music teaching in colleges and universities has made extraordinary achievements in our country, but we also should see the problems in it. At present, many educators in related fields have made some theoretical and practical research and exploration on how to improve the effect of music teaching in colleges and universities, and achieved certain results. As a first-line teaching teacher, the author also has carried on the long-term tracking and research to the related theory and practice progress. In this process, the author finds that musical and cultural factors in our music teaching is a long-term neglected part. Music is a highly integrated art form. At present, music teaching in colleges and universities is mainly focused on the basic professional theory, performance, teaching basic skills and other aspects. And there is a shortage of exposure and inculcation of musical and cultural factors.

Music teaching needs the right idea firstly. The author thinks that music teaching can not be simply regarded as teaching, but should be regarded as the exploration in the related fields. We should lead students to explore their past and explore their future, and try to explore the soluble elements in this field in teaching, and make the teaching and application elements in this field more colorful. Under the background of quality education, the goal of college education teaching is to cultivate the overall quality of students, not only to teach students a single skill. The introduction of music culture factors into college music teaching can not only cultivate comprehensive music perception ability of students, but also improve their cultural literacy.
\end{abstract}

\section{Concept of Musical and Cultural Factors}

Musical and cultural factors are broad concepts, which refer to the cultural factors and cultural forms contained in the related musical works or some form of music. Musical and cultural factors are concepts that evolve with the times and contain different contents in specific historical periods. They are gradually enriched with the development of music. For example, China is a multinational country, including fifty-six nationalities, and the music style of each nation has its own unique characteristics. The Han nationality have yangko, suona, lion dance and others, Uygur have tambourine music, Tibetan have a three-stringed plucked instrument dance music and so on...... There is an inseparable relationship between the music of every nation and the national culture, and the music of different nationalities and periods is different. The influence of regional environment on music also obviously, such as the hills and mountains in the south, lingering water, where the folk songs turn melodious. In the northern unique landforms environment, the northern music is mostly bold and rough. Similarly, there is a significant difference between Chinese and western music. The changes in the form and content of these music reflect the cultural differences of humanistic temperament, geographical environment and so on from one side. Culture is a nation, a long-term accumulation of things in the region, into the blood of the nation and the people of the 
soul. Culture is a kind of thought, a kind of habit, even is a kind of expression. Music works from a certain point of view is the people's expression of culture, is a form of recording people's happiness and sorrow. It determines that music is inseparable from the influence of cultural factors, and there is every place in music that contains cultural factors.

In terms of carrier, music is just one case of culture and art. As the artistic form of many cultural carriers, the relationship between music and poetry, comedy, literature, and painting has a distant origin and a long development. They share the same roots with each other, connect to each other, have mutual influence, and phase together. The word poetry itself is very representative. In ancient China, poetry was often presented in the form of music. There are poems in music, and music is abound in poetry. They are mingled with each other and benefited by associating together. Poetry has become an indispensable cultural symbol and cultural factors in music in neat order. The relationship between music and literature is countless, and many literary works have corresponding musical representation. As we are familiar with " The love of two butterflies", "Romeo and Juliet", and so on, the literary works are all presented in the form of music. Although this is not a reproduction of literary works, it sublimates the spirit and content inherent in literary works on the spiritual level. There is also a colorful connection between music and painting, music and dance. No matter how the art form changes, it is always the same. We can always follow this source and find the corresponding symbol of cultural factors. This is why many people hear or see a form of art that can distinguish whether they are from the nation and the cause of the country.

Music cultural factors have strong historical feelings. When the Pipa song "ambush on all sides" sounded, it suddenly seems to take us into the ancient war battlefield. The melodious cheerful song "Hope on the field" eagerly look forward people's though to to a busy construction years ...... Music can lead us to pass-through time and space with thousands of years, and fill our mind with a myriad of thoughts and ideas when the sound of the piano rings.Music works are always created in a specific historical period, and it is unavoidable to be branded with historical culture.

\section{The Present Situation of Music Teaching in Colleges and Universities}

At present, our country's education investment has been borne by the national finance. Because of the previous policy factors, the investment of music teaching in colleges and universities can not meet the actual needs of professional construction and development. Since the end of the last century, the relevant national education departments have taken the students' comprehensive ability and quality as the goal of cultivating college students, and the music curriculum has been gradually paid valued. But there are still such deficiencies in enrollment, course offered, investment in teachers, construction of teachers, hardware facilities, software facilities and other aspects.

The quality of students is not high. In the teaching reform, due to the expansion of enrollment, some students with poor professional quality and cultural quality can also be admitted to the music major. Overall, the decline in the quality of students over the years is serious. In a sense, music major in colleges and universities has become a shelter for low-grade students.

The teachers are inadequate. The music discipline is very special, not only needs a certain professional teacher with a certain ability, but also must have a matching equipment and teaching environment. However, as far as the current situation is concerned, many colleges and universities have old facilities or equipment, or they can not meet the requirements of normal teaching order.

The teaching does not pay attention to the individual development of students. Music specialty students in colleges and universities have strong professional consciousness and performance consciousness. However, many colleges and universities do not take into account the characteristics of the students in curriculum planning, course arrangements and other aspects. They take in professional education teaching mode with a straightforward way, so that the individual development of students is greatly restricted.

Negative effects of the social environment. The social environment has a great influence on the construction of colleges and universities. Nowadays, many people still have the old understanding of music teaching. Even some people think that students trained by music professionals do not have any social value except the function of entertainment. In many occasions and fields, elegant forms 
of music have been replaced by vulgar and low - style art forms. The holy art forms are also infected with too much stink of money. Some of the media's one-sided reports have also exacerbated the social bias on music teaching.

\section{The Historical Mission of Music Teaching in Colleges and Universities in the New Period}

Music teaching is an important part of higher education. Its mission is to cultivate and export outstanding professional talents for the modernization drive. With the economic and social development and continuous improvement of people's living standard, people's pursuit of spiritual and cultural level has exploded. Music teaching has a special and urgent historical mission in the new historical period. In music teaching, teachers should not simply teach basic theories, audiovisual and other knowledge, but attach importance to teaching and explaining of students cultural factors in music teaching. At the same time of nurturing and shaping the aesthetic ability of students, We should put forth efforts to build the cultural knowledge of the students. Only a short while ago, we are almost utterly routed in the field of culture. On the streets and the campus dormitory, we heard the ears is basically full of exotic and other country's style.

Music teaching in colleges and universities is the forefront of cultural protection. We should lead the students to actively explore and pursue in our own music culture treasure house, and let the splendid culture bloom the flower of music. We must strive to make traditional music education and teaching become an important way to spread music culture, and become an important way to spread traditional ideas, traditional values and traditional humanistic customs. In this, the teacher is a very important role. We should abandon the inherent and traditional teaching mode, with the identity of cultural protectors, cultural excavators, cultural inheritors to do a good job in college music teaching. This is the demand for the development of higher education in the new period, and also the inner embodiment of the quality education.

\section{The Function of Musical and Cultural Factors in Teaching}

Attaching importance to the learning of musical culture factors can not only help students expand their knowledge, but also help students develop their spirit of exploration and innovation, and improve their comprehensive quality. The " music curriculum standards" pointed out that music and cultural factors are the concentrated expression of the humanistic attributes in music lessons, which can improve the cultural quality of students. It can effectively expand the students' music vision, improve the students' music perception and experience, improve the students' music appreciation ability and aesthetic ability.

In college music teaching materials, many music works have profound cultural connotations. They have magnificent and gorgeous national music culture, but also have rich and colorful world music culture. In these music works, we can lead the students to understand the local customs and practices of different countries, and can also lead them into the music hall of Beethoven and Mozart. Through the interpretation and exploration of musical and cultural factors, students can greatly broaden their horizons and enrich their understanding and experience of music.

Music is the most emotional form of art, people for certain specific things of the senses can be realized through music. For example, in the explanation of "The love of two butterflies", teachers can introduce students to the current social background and historical knowledge. Let the students down the river of history, deeply understand the tragic picture of struggle for love in "The love of two butterflies", let them seem to personally feel the long and sad time. Music teaching also bears the responsibility of cultivating students' creative ability. But this kind of creation must be based on a certain cultural material. Through continuous accumulation of cultural factors, students will integrate material and professional skills, and gradually sublimate sense and understanding, which will help to improve their creative ability.

The teaching of music and cultural factors puts forward high requirements for teachers. On the one hand, it requires the instructor to have a very wide range of knowledge, on the other hand, it also improves the teaching skills standard in the classroom. As far as the current faculty strength of 
higher education institutions in our country is concerned, it is unrealistic to achieve the ideal teaching effect. However, at the school level, we should strengthen the training and training potency dimension of music teachers in colleges and universities, so that teachers can have the opportunity to participate in the relevant fields as much as possible. On the other hand, teachers should also formulate their own development plans. They should strive to improve their comprehensive literacy, constantly enrich their own knowledge system, improve their teaching skills and enhance their teaching methods.

\section{Some Matters Needing Attention in Musical and Cultural Factor Teaching}

As a whole, the role of musical and cultural factors in promoting music teaching in colleges and universities is obvious. However, in the implementation of specific courses, we also need to pay attention to the following questions:

\section{Focus on the Diversity of Musical Forms}

When we choose the content of teaching, we should introduce as much form of music as possible. One is due to the characteristics of young students themselves. They have a strong curiosity about the unknown things, but if the form is too single, it is easy for students to get bored after a period of teaching. This requires schools and teachers to arrange courses and teaching progress reasonably. In the course of teaching, teachers should try to make the students participate actively and improve their sense of participation. When students show a strong interest or unique opinion on a problem, the teacher should actively guide and adjust the course schedule. When curriculum time permits, teachers should try their best to arrange students to participate in the discussion, so as to make some students learn and understand some ideas in the collision.

\section{Teachers Should Take Specialty as the Guidance to Develop Creative Ability of Students}

On the basis of mastering the basic knowledge and basic skills of this major, music professional students in colleges and universities should constantly expand their thinking, transform professional knowledge into ability literacy, and improve their own innovative ability. Students should be good at using the music elements of traditional culture, and transform the corruptible into mysterious life. In the course of teaching, we should provide the students with a relatively relaxed development environment and fully explore the characteristics of the students. We should guide students to interest as the starting point, bold practice in a relaxed and pleasant environment, and strive to explore.

\section{Establish a Supporting Assessment Mechanism}

The establishment of assessment mechanism should fully consider the characteristics of curriculum design. In the assessment, musical and cultural factors should occupy a considerable proportion. The assessment system should be scientific, accord with the curriculum design, and has a strong operability. We should change the malpractice of traditional assessment mechanism, which attach importance to the basic theory of music, and incorporate musical and cultural factors into the assessment, so as to effectively guide learning goals of students.

\section{Reference Documentation}

[1] Copland. How to Appreciate Music [M]. Beijing: People's Music Publishing House, 1984.

[2] Li Aizhen. Analysis of Music Education Management Mode in Colleges and Universities in China [D]. Beijing: Capital Normal University, 2006.

[3] Pei long. Research on the Public Music Education Management Mechanism in Colleges and Universities [J]. Trade Union Expo. Theoretical Research, 2009 (1).

[4] Zhang Qian, Wang Cizhao. Music Aesthetics Foundation[M]. People's Publishing House, 1995.

[5] Zhang Hongdao. Europe Music History [M]. Beijing: People's Music Publishing House, 2005.

[6] Bu Genhai. The Power of Music [ M ]. Shanghai: Shanghai Literature and Art Publishing House, 1991.2.

[7] Shen Bo. Some Thoughts on Strengthening the Professional Construction of Higher Vocational College [J]. Journal of Shanxi Youth Management Cadre College, 2003, (4). 
[8] Yang Mingang. The Thinking of Sustainable Development of China's Higher Vocational Colleges and Universities [J]. China's Vocational and Technical Education, 2008 (9).

[9] Dong Yuepeng. The Thinking of Higher Vocational Music Education [J]. The Window of Contemporary Education, 2010, (4).

[10] Yang Chunlin. A Brief Discussion on The Teaching of Music Appreciation Course in Colleges and Universities [J]. Journal of Changchun Normal University, 2012, (07).

[11] Tian Juanjuan. Research on The Teaching of Public Music Appreciation in Colleges and Universities [J]. Popular Literature and Art, 2013, (05).

[12] Mao Qiusi. A Brief Discussion on The Music Appreciation Courses Under the Multimedia Teaching Environment in Colleges and Universities [J]. Journal of Youth, 2012, (18) 